\title{
Towards an Educational Platform with Real-Time Collaboration and Monitoring of Students Achievement
}

\author{
Paulo Silas Severo de Souza, Wagner dos Santos Marques, \\ Jaline Gonçalves Mombach
}

\author{
${ }^{1}$ Instituto Federal Farroupilha (IF Farroupilha) \\ Campus Alegrete - RS - Brasil \\ \{paulo.souza, wagner.marques\}@email.com, \\ jaline.mombach@iffarroupilha.edu.br
}

\begin{abstract}
Several studies have been undertaken aiming to improve the efficiency of e-learning through the development of features to Virtual Learning Environments. However, such researches have no focus on the use of collaboration of learning objects and analysis of students' progress in real-time. Hence, this paper presents an educational platform that allows real-time co-authorship and monitoring of students' progress in learning objects, through the implementation of software engineering techniques and patterns designed for educational systems.
\end{abstract}

Resumo. Diversos estudos têm sido empreendidos visando aumentar a eficiência da aprendizagem à distância, por meio do desenvolvimento de funcionalidades para Ambientes Virtuais de Aprendizagem. Todavia, estas pesquisas não possuem foco no uso de colaboração de objetos de aprendizagem e análise do progresso dos alunos, em tempo real. Por isto, este artigo apresenta uma plataforma educacional que permite coautoria em tempo real e acompanhamento do progresso de alunos em objetos de aprendizagem, através da implementação de técnicas de engenharia de software e padrões de sistemas educacionais.

\section{Introduction}

In the educational context, there is a concern about the prevention of learning issues such as misunderstood concepts, which can create gaps of knowledge that can induce students to school dropout (LAMB EIFRED MARKUSSEN, 2011). In the Computing courses context, there are some disciplines, such as Introduction to Algorithms, which concepts serve as basis to subsequent disciplines. Although, newcomer students usually have some issues on these disciplines, since it require an efficient usage of the cognitive processes, such as abstraction and formalization, in order to model a problem's solution through a computational code (FALCKEMBACH; ARAUJO, 2013).

In this sense, the Information and Communication Technologies (ICTs) emerge as a viable solution to combat the gaps of knowledge created by misunderstanding of theoretical concepts, since it permits the use of analytical tools which provide a accurate analysis of student's learning progress, allowing teachers to quickly identify student's learning difficulties (WHITE; LARUSSON, 2014). 
Beyond providing an analysis of the students' learning progress, analytical tools can also provide a feedback regarding the efficiency of each used activity (e.g., puzzles, questionnaires, hunting words games, etc.), so teachers can adapt the pedagogical contents in order to meet the students' needs. Moreover, applications supporting real-time collaboration (e.g., wikis and Google Drive ${ }^{1}$ ) has been used to ease the development of contents suitable to students needs and improve the teamwork during the proposed activities (GARNER, 2010).

Therefore, several researches have been undertaken aiming to ease the collaboration on educational environments (RODRIGUES et al., 2014; LUCENA; SILVA; OLIVEIRA, 2015; MAZZA; DIMITROVA, 2007; ZORRILLA; ÁLVAREZ, 2008; SIQUEIRA; PINHATI, 2015). Nonetheless, neither of these studies have provided both collaboration of learning objects and monitoring of students' progress in real time. Thus, this paper presents a pedagogical platform with the following main contributions:

- Real-time collaboration: the proposed platform allows teachers collaboration during the development of learning objects.

- Learning objects sharing: our proposal gives teachers the possibility of easily share their learning objects to other teachers which use the platform.

- Learning Analytics: such platform provides a detailed feedback of students progress in real time (e.g., which questions took more time to be responded on a questionnaire).

The remaining part of this study is organized as follows. In Section 3, we show the theoretical background which served as basis to the development of the proposed platform; in Section 2 we discuss about related researches; Section 4 is reserved for the explanation of the proposal; and in Section 6 we present the final remarks.

\section{Related Work}

Rodrigues et al. (2014) have been proposed a tool based on multi-agents architecture, that allows the creation of customized learning objects. Furthermore, Lucena, Silva e Oliveira (2015) have developed a plugin to Moodle VLE, that allows monitoring students' activities, by using TreeMap technology, that graphically organizes the results in a hierarchical manner.

Mazza e Dimitrova (2007) also emphasizes monitoring of students' performance by proposing a tool where several graphical presentations are generated aiming to help tutors in trend identification (e.g., students who need special attention). Likewise, Zorrilla e Álvarez (2008) proposed a tool that provides educational reports using general guidelines for design of business intelligence applications. Moreover, Siqueira e Pinhati (2015) have proposed an application that allows the development of learning activities with emphasis in multimedia materials.

What differentiates our work from the other covered in this section is to unite the real-time collaboration to monitor students' achievements. In addition, the proposed platform will also be available for mobile devices, such as smartphones and tablets.

\footnotetext{
${ }^{1}$ Available at: $<$ https://drive.google.com $>$.
} 


\section{Background}

In this section, we present the theoretical background about the use of collaborative approaches' usage on the educational context. Moreover, we show some concepts, such as learning environments and virtual learning environments, which will pave the way to the proposed platform.

\subsection{Collaboration on Education}

The increasingly use of technological elements to improve the quality of processes has contributed to the rise of service-based organizations. Hence, it's becoming even more common companies which improve their processes by sharing resources independently of its culture, primary language and location. In this sense, collaboration and teamwork are becoming essential skills to ensure the professional success (SPIELBERGER, 2004).

On the educational context, the collaboration is also a very important element: teachers can exchange knowledge with each other, creating more efficient pedagogical materials, and students can improve their skills by working together with their colleagues.

In this sense, technology can ease the collaboration on this scenario through elements like Learning Objects (LOs), which are digital resources created based on the idea of objects (which comes from the Object-Oriented programming paradigm), that are elements that can be reused on multiple contexts. Thus, the idea behind learning objects is to allow the creation of instructional components that can be reused several times in different learning contexts. So, LOs favour the collaboration, since teachers can exchange such materials, adapting it to their student's needs (WILEY, 2001).

Moreover, there are digital environments developed in order to ease the use of pedagogical materials by students and teachers. Such environments are called Virtual Learning Environments (VLEs), which are softwares whose objective is support teaching and learning activities through the internet. More specifically, VLEs are preconfigured platforms which provide an integrated set of tools that allow the manipulation of educational materials without requiring an advanced technical knowledge in computing, such as programming. Furthermore, these environments allow teachers to share materials with their students and also evaluate their progress, which allow its use on both classroom and on-line courses (O'LEARY; RAMSDEN, 2002).

Thus, in this paper we present an educational platform which unifies the concepts behind learning objects and virtual learning environments. Our proposal allows the collaborative creation and usage of learning objects. In addiction, teachers can share their materials with their colleagues, and analyze their students progress in real-time.

\section{Materials and Methods}

In this Section we present which methodology, technologies and techniques had been used on the development of the proposed platform.

\subsection{Educational Systems Patterns}

Usability is a very important subject on software development, since this area is related to the use of techniques, guidelines, and methods developed in order to ensure that the software product is easy to use and it covers its user's needs and objectives. 
In this sense, the development process of the proposed platform is guided by 9 design patterns introduced by Silva e Anacleto (2015), which are recommended to educational systems that allow co-authorship of its contents:

i) co-authorship Option: the system should clearly inform to the users the possibility of co-authorship.

ii) Synthesis: the application's objective should be explained in a simple way, preferentially at the first page

iii) Objective: the application's objective should be presented succinctly to the co-author, near to the system's rules.

iv) Information: the system should define which information should be informed by the co-author.

v) User: stipules an analysis of which information should be requested at the users registration.

vi) Steps: determines the division of the processes on steps, i.e., the information should be requested separately, avoiding user confusion. Only information directly related should be requested at the same page.

vii) Steps' Characteristics: the user should be able to both go back to previous steps or even advance to posterior steps.

viii) What need to be done: the application should present an explanation of what need to be done on every step.

ix) Content Reuse: the system should clearly present the customization feature (e.i., features of editing, reusing, and insertion).

\subsection{Software Engineering Resources}

In software engineering, modeling languages offer specifications that allow improvements in systems design. For this, those languages stipulate rules and patterns of development. One of the most known modeling languages is UML (Unified Modeling Language), that can be used in different kinds of projects, covering aspects such as requirements and dataflow (STEPHENS, 2015). Thus, UML diagrams will be used to improve the architectural design and the efficiency of developers on the proposed platform.

SCRUM is a software engineering agile technique based on agile development that aims to increase developers' productivity and increase the interaction between stakeholders. By its flexibility, SCRUM can be used in projects of different spreads (BISSI, 2007; MEIRELES; BONIFÁCIO, 2015). Such technique focuses on reducing the documentation and giving more importance to the software development. In addition, SCRUM is characterized for its iterative and incremental development method: SCRUM divides the software development in a series of interactions (called sprints) which takes one to four weeks. Each sprint involves the development of some features which are coded, tested and integrated into the system. In this sense, users can access the system even when it is not completed yet. Regarding project planning, SCRUM promotes meetings with the stakeholders for planning, reviewing and retrospection. (SINDHGATTA; NARENDRA; SENGUPTA, 2010).

SCRUM can also be used along with other techniques, such as Test-Driven Development (TDD). TDD is a software engineering technique which suggests the creation of tests before the implementation of the application features. Thus, the coding process using TDD is guided by the tests' specifications previously defined. The use of such technique 
brings several benefits to the software project, such as improvements in the architecture (on a context in which an object-oriented programming language is used, the features' development based on tests can improve the design of systems' classes) and increasing the speed of the development (since all tests are written before the coding process, the developers can execute it, quickly identifying problems). Moreover, the use of TDD with SCRUM can improve the software architecture's design and usability (SOARES; CABRAL; ALENCAR, 2013).

Moreover, the proposed platform will be developed using Ruby on Rails ${ }^{2}$ (which is a very known web framework built with the Ruby programming language ${ }^{3}$ ). Such technology was chosen since it uses the REST (Representational State Transfer) architectural style, which eases the development of web platforms by representing the application resources as URLs (Uniform Resource Locators). Moreover, Ruby on Rails also facilitates the development of asynchronous features through the ActionCable class (BRADBURNE, 2016). This feature will be used in the implementation of the real-time features provided by the proposed platform (such as monitoring of students achievement and realtime collaboration during the development of activities).

\section{Proposed Platform}

Firstly, we analyzed the functional and non-functional requirements of the proposed platform. The non-functional requirements, presented in Table 1, illustrate the characteristics and internal aspects which the software need to have (e.g., security and usability). functional requirements represent the features of the application (e.g., activities management and users registration). The description of such requirements are shown in Table 2 (SILVA; BARROSO et al., 2016).

Table 1. Non-functional requirements (desired characteristics) of the platform.

\begin{tabular}{|l|l|}
\hline Requirement & Description \\
\hline Performance & $\begin{array}{l}\text { The system must perform well during the execution of all the available features, } \\
\text { presenting a loading time no longer than 4 seconds. In addition, the application } \\
\text { must support up to 10000 concurrent users without presenting performance lacks. }\end{array}$ \\
\hline Security & $\begin{array}{l}\text { The platform' features which involve interaction with the database must require } \\
\text { user authentication. Moreover, private information such as passwords must be } \\
\text { encrypted on the database. }\end{array}$ \\
\hline Responsiveness & $\begin{array}{l}\text { The proposed platform (which will be developed in a web environment) must be } \\
\text { developed using responsive design guidelines, e.i., the application interface must } \\
\text { automatically adjust itself to the dimensions of different devices (e.g., tablets, } \\
\text { smartphones, and computers). }\end{array}$ \\
\hline Usability & $\begin{array}{l}\text { The system' features must be presented in order to ease the users' interaction. } \\
\text { More specifically, a study must be carried out in order to analyze which colors } \\
\text { should be used and how the elements should be arranged on the platform. }\end{array}$ \\
\hline Availability & $\begin{array}{l}\text { The system must have a uptime of at least } 98 \% \text {. In addition, when some error } \\
\text { happens, the application should send a warning e-mail to the administrator. }\end{array}$ \\
\hline
\end{tabular}

After the identification of the system requirements, we analyzed how the users would interact with the application. A use case diagram is presented in Figure 1.

\footnotetext{
${ }^{2}$ Available at: $<$ http://rubyonrails.org $>$.

${ }^{3}$ Available at: $<$ https://www.ruby-lang.org/pt $>$.
} 
Table 2. Functional requirements (features) of the proposed platform.

\begin{tabular}{|l|l|l|}
\hline Requirement & Description & $\begin{array}{l}\text { Priority } \\
\text { Level }\end{array}$ \\
\hline Users' Management & $\begin{array}{l}\text { The system must provide features related to users management (login, } \\
\text { registration, editing accounts). }\end{array}$ & Essential \\
\hline $\begin{array}{l}\text { Sharing and } \\
\text { manipulation } \\
\text { of Activities }\end{array}$ & $\begin{array}{l}\text { On the platform, teachers should be able to create and share activities } \\
\text { with their students. Moreover, teachers should also be able to collaborate } \\
\text { on the development of other teachers' activities. }\end{array}$ & Essential \\
\hline $\begin{array}{l}\text { Monitoring of } \\
\text { Students' Achievement }\end{array}$ & Teachers should be able to analyze their students' achievements. & Important \\
\hline Statistical Information & $\begin{array}{l}\text { Administrators should have access to analytical information about } \\
\text { the users and about the created activities. }\end{array}$ & Desirable \\
\hline
\end{tabular}

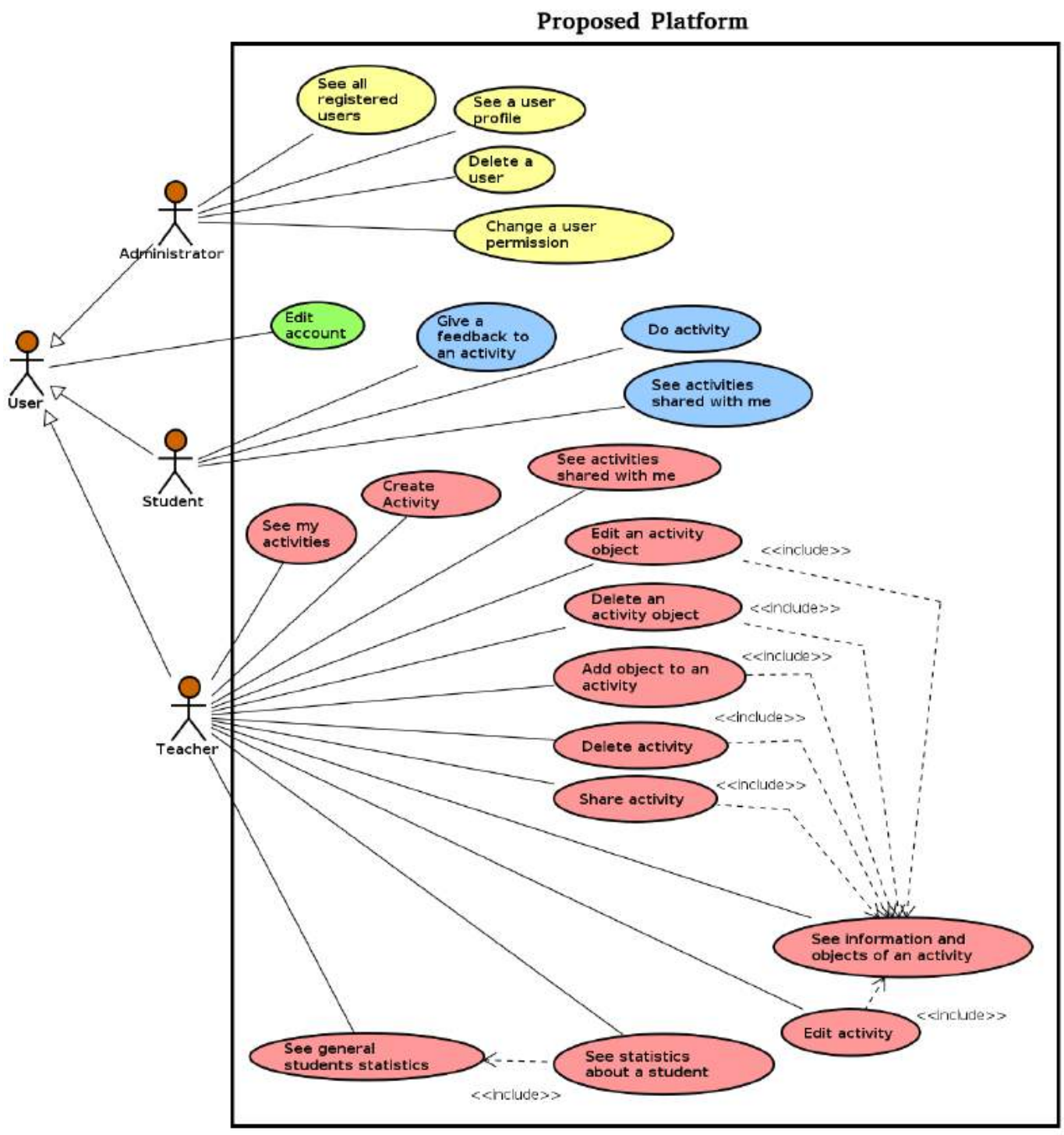

Figure 1. Use case diagram of the proposed platform which demonstrates which features will be available to each user level.

The use case diagram was developed in order to provide a holistic view of the features which would be present on the proposed platform. In this phase, we identified 
that the application should have 3 users' levels:

- Administrators: would have access to the statistical module of the platform (shown in Figure 3), which presents information about the system and its users (e.g., types of registered activities, more active teachers, evolution of the number of registered users, etc.).

- Teachers: would be able to create, edit, share activities with their students, and also invite other teachers to collaborate on the development of their activities. Moreover, teachers would also be able to create public activities, which would be available to all registered students, and would be cloned and edited by other teachers (without a need of invitation).

- Students: would be able to participate in activities, interacting with their colleagues and teachers through activity's comments. More specifically, students will have access to activities through codes which will be provided by their teachers. Such process is shown in Figure 2.

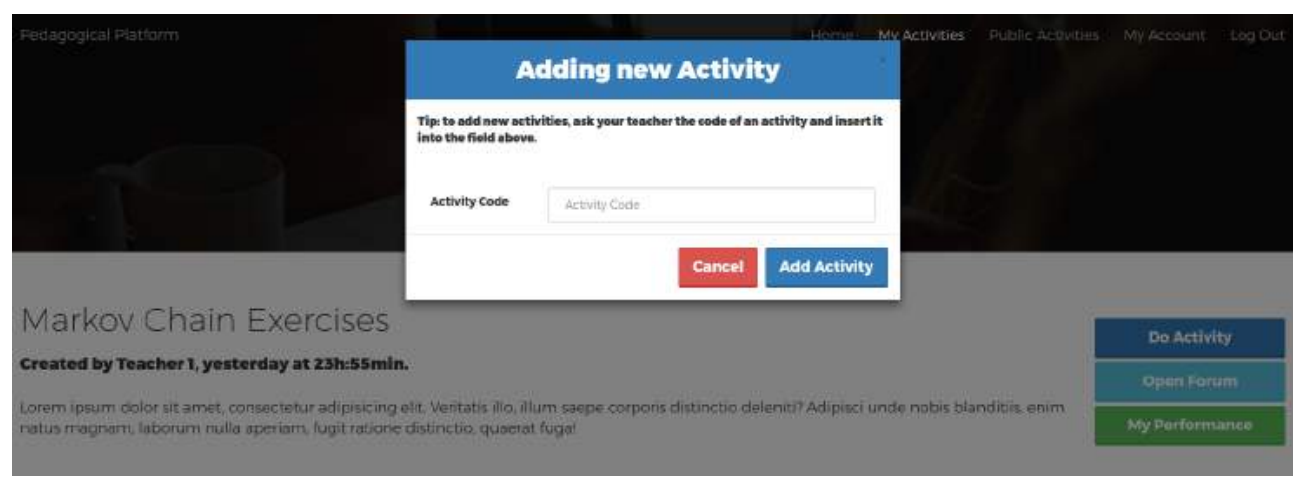

Figure 2. On the proposed platform, teachers will be able to choose if their activities will be public or private. Public activities will be available to all students registered on the platform, and the private ones will be only accessible through a code.

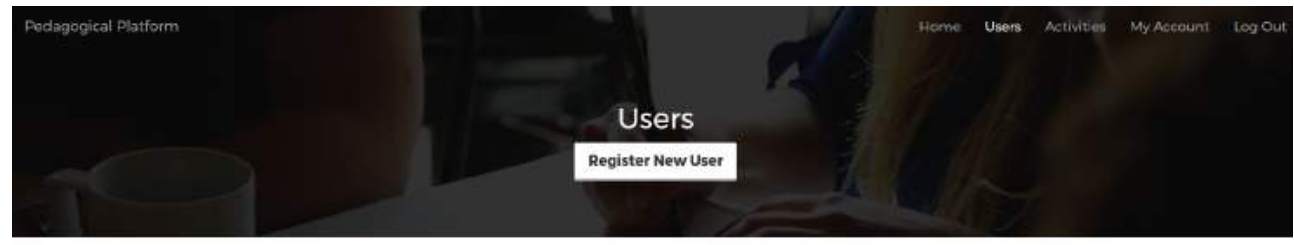

Statistics

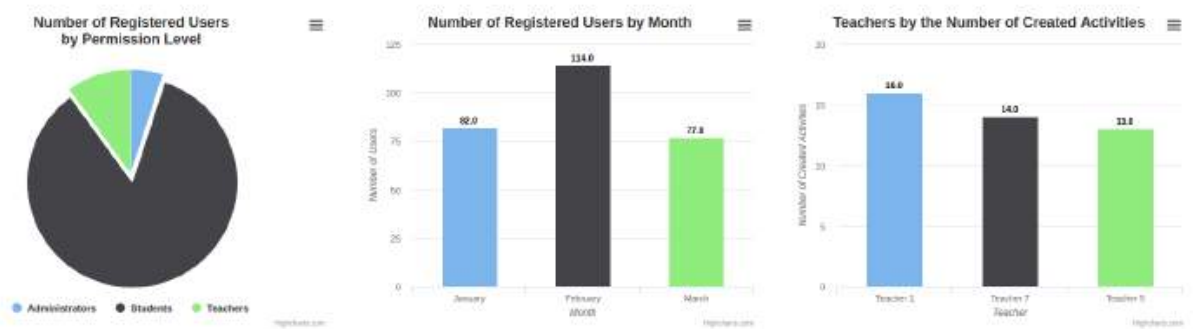

Figure 3. Administrators will be able to create new users (students, teachers, and administrators), and will have access to statistics about the registered users. 


\section{Conclusions}

The majority of Virtual Learning Environments offer a lot of information that can be used in evaluation and monitoring of students (e.g. participation index, access horary, and final results of tests). Nonetheless, the majority of such information are used by quantitative analysis, which only collects data at the end of pedagogical activities or even at the conclusion of the discipline, hampering the detection and the decision-making based on students' learning difficulties during the pedagogical process (ALMEIDA; PIMENTEL; STIUBIENER, 2012).

In this sense, the collaboration of this paper consists in the proposition of a pedagogical platform that allows the co-authorship of learning objects, with the possibility of real-time collaboration between teachers. Moreover, teachers can share such resources with students, and analyze their progress, quantitatively and qualitatively. Currently, such platform is been developed. In this sense, as future work, we intend to finish its development and implement intelligent agents to help teachers on decision-making based on students achievement.

\section{References}

ALMEIDA, A.; PIMENTEL, E. P.; STIUBIENER, I. Estratégias para o monitoramento de ações de tutoria na educação a distância. In: Anais dos Workshops do Congresso Brasileiro de Informática na Educação. [S.1.: s.n.], 2012. v. 1, n. 1.

BISSI, W. Metodologia de desenvolvimento ágil. Campo Digital, v. 2, n. 1, 2007.

BRADBURNE, A. Rails 5 revealed. [S.1.]: Springer, 2016.

FALCKEMBACH, G. A. M.; ARAUJO, F. V. de. Aprendizagem de algoritmos: dificuldades na resolução de problemas. Anais Sulcomp, v. 2, 2013.

GARNER, S. Supporting the personal knowledge management of students with technology. In: Proceedings of Informing Science \& IT Education Conference (InSITE). [S.1.: s.n.], 2010. p. 237-246.

LAMB EIFRED MARKUSSEN, R. T. J. P. N. S. S. School dropout and completion international comparative studies in theory and policy. Dordrecht: Springer Netherlands, 2011. ISBN 978-90-481-9762-0,978-90-481-9763-7.

LUCENA, K. T.; SILVA, J.; OLIVEIRA, E. Webmonitor: uma ferramenta para monitoramento e acompanhamento de cursos em um ava. In: Anais do Simpósio Brasileiro de Informática na Educação. [S.1.: s.n.], 2015. v. 26, n. 1, p. 249.

MAZZA, R.; DIMITROVA, V. Coursevis: A graphical student monitoring tool for supporting instructors in web-based distance courses. International Journal of Human-Computer Studies, Elsevier, v. 65, n. 2, p. 125-139, 2007.

MEIRELES, M. C.; BONIFÁCIO, B. Uso de métodos ágeis e aprendizagem baseada em problema no ensino de engenharia de software: Um relato de experiência. In: Anais do Simpósio Brasileiro de Informática na Educação. [S.1.: s.n.], 2015. v. 26, n. 1, p. 180.

O'LEARY, R.; RAMSDEN, A. Virtual learning environments. Learning and Teaching Support Network Generic Centre/ALT Guides, LTSN. Retrieved July, v. 12, p. 2005, 2002. 
RODRIGUES, A. M. et al. Saapiens: Uma ferramenta de autoria de objetos de aprendizagem e apoio pedagógico na dedução natural na lógica proposicional. In: Anais do Simpósio Brasileiro de Informática na Educação. [S.1.: s.n.], 2014. v. 25, n. 1, p. 1003.

SILVA, A.; BARROSO, J. et al. A survey about the situation of the elicitation of non-functional requirements. In: IEEE. 2016 11th Iberian Conference on Information Systems and Technologies (CISTI). [S.1.], 2016. p. 1-6.

SILVA, M. A. R.; ANACLETO, J. C. Formalização e validação de padrões para apoiar o design de sistemas educacionais com coautoria. Revista Brasileira de Informática na Educação, v. 23, n. 01, p. 43, 2015.

SINDHGATTA, R.; NARENDRA, N. C.; SENGUPTA, B. Software evolution in agile development: a case study. In: ACM. Proceedings of the ACM international conference companion on Object oriented programming systems languages and applications companion. [S.1.], 2010. p. 105-114.

SIQUEIRA, S. W. M.; PINHATI, F. Plataforma mignone: Ambiente virtual de aprendizagem e objetos de aprendizagem especializados para a educação musical. Revista Brasileira de Informática na Educação, v. 23, n. 02, p. 1, 2015.

SOARES, R.; CABRAL, T.; ALENCAR, F. M. Gerenciamento de requisitos em scrum baseado em test driven development. In: ER@BR. [S.1.: s.n.], 2013.

SPIELBERGER, C. Encyclopedia of applied psychology. [S.1.]: Academic Press, 2004.

STEPHENS, R. Beginning Software Engineering. [S.1.]: John Wiley \& Sons, 2015.

WHITE, B.; LARUSSON, J. A. Identifying points for pedagogical intervention based on student writing: Two case studies for the "point of originality". In: Learning Analytics. [S.1.]: Springer, 2014. p. 157-190.

WILEY, D. A. Instructional use of learning objects. [S.1.]: Agency for Instructional Technology, 2001.

ZORRILLA, M. E.; ÁLVAREZ, E. Matep: Monitoring and analysis tool for e-learning platforms. In: IEEE. 2008 Eighth IEEE International Conference on Advanced Learning Technologies. [S.1.], 2008. p. 611-613. 